\title{
Allosteric Modulators of the $\mathrm{CB}_{1}$ Cannabinoid Receptor: A Structural Update Review
}

\author{
Paula Morales, Pilar Goya, Nadine Jagerovic, and Laura Hernandez-Folgado*
}

\begin{abstract}
In 2005, the first evidence of an allosteric binding site at the $C_{1} R$ was provided by the identification of three indoles of the company Organon that were allosteric enhancers of agonist binding affinity and, functionally, allosteric inhibitors of agonist activity. Since then, structure-activity relationships of indoles as $C_{1} R$ modulators have been reported. Targeting the allosteric site on $\mathrm{CB}_{1} \mathrm{R}$, new families structurally based on urea and on 3phenyltropane analogs of cocaine have been discovered as $\mathrm{CB}_{1} \mathrm{R}$-negative allosteric modulators (NAMs), respectively, by Prosidion and by the Research Triangle Park. Endogenous allosteric ligands of different nature have been identified more recently. Thus, the therapeutic neuroprotection application of lipoxin A4, an arachidonic acid derivative, as an allosteric enhancer of $\mathrm{CB}_{1} \mathrm{R}$ activity has been confirmed in vivo. It was also the case of the steroid hormone, pregnenolone, whose negative allosteric effects on $\Delta^{9}$-tetrahydrocannabinol $\left(\Delta^{9}\right.$-THC) were reproduced in vivo in a behavioral tetrad model and in food intake and memory impairment assays. Curiously, the peroxisome proliferator-activated receptor- $\gamma$ agonist fenofibrate or polypeptides such as pepcan-12 have been shown to act on the endocannabinoid system through $\mathrm{CB}_{1} \mathrm{R}$ allosteric modulation. The mechanistic bases of the effects of the phytocannabinoid cannabidiol (CBD) are still not fully explained. However, there is evidence that CBD behaves as an NAM of $\Delta^{9}$-THC- and 2-AG. Allosteric modulation at $\mathrm{CB}_{1} \mathrm{R}$ offers new opportunities for therapeutic applications. Therefore, further understanding of the chemical features required for allosteric modulation as well as their orthosteric probe dependence may broaden novel approaches for fine-tuning the signaling pathways of the $\mathrm{CB}_{1} \mathrm{R}$.
\end{abstract}

Key words: $C B_{1} R$; synthetic cannabinoids

\section{Introduction}

One traditional way of designing new drugs is the socalled one target-one disease approach. Indeed, this is the case of many commercially available drugs, which interact with enzymes, receptors, or ionic channels among others. One of the most important targets are the G-protein-coupled receptors (GPCRs) for which agonists and antagonist/inverse agonists have been developed.

These traditional ligands bind to the same site as the endogenous ligand, the so-called orthosteric site. However, recently, research has shifted to compounds that can interact with a different region of the receptor, termed the allosteric site, since this approach may result in pharmacological advantages such as higher specificity and thus reduced side effects. The best known mechanisms of action of these allosteric ligands are activation or inhibition of the receptor signaling, referred to as positive allosteric modulators (PAMs) and negative allosteric modulators (NAMs). There are also neutral or silent ligands, silent allosteric modulators, which do bind to the allosteric site without affecting the response of the endogenous agonist. In addition, bitopic ligands that bind to both the orthosteric and

Instituto de Química Médica, Consejo Superior de Investigaciones Científicas, Madrid, Spain.

*Address correspondence to: Dr. Laura Hernandez-Folgado, Instituto de Química Médica, Consejo Superior de Investigaciones Científicas, Calle Juan de la Cierva 3, Madrid E-28006, Spain. E-mail: Ihernandez@iqm.csic.es

(C) Paula Morales et al. 2016; Published by Mary Ann Liebert, Inc. This Open Access article is distributed under the terms of the Creative Commons License (http://creativecommons.org/licenses/by/4.0), which permits unrestricted use, distribution, and reproduction in any medium, provided the original work is properly credited. 
allosteric sites have been described. In the last years, there has been considerable research in allosteric modulation of GPCRs both in academia and industry, ${ }^{1,2}$ and structural knowledge on how these interactions take place has advanced on the basis that some cocrystals of a ligand bound to an allosteric site have been obtained. $^{3}$

In addition to two allosteric modulators marketed for HIV and hyperparathyroidism, recent potential therapeutic applications of allosteric modulators of GPCRs include central nervous system (CNS) disorders such as neurodegenerative diseases or schizophrenia $^{4}$ and also pain for which PAMs of the $\mu$-opioid receptor have been proposed. ${ }^{5}$

A particular kind of GPCRs are the cannabinoid $\mathrm{CB}_{1}$ and $\mathrm{CB}_{2}$ receptors $\left(\mathrm{CB}_{1} \mathrm{R}\right.$ and $\left.\mathrm{CB}_{2} \mathrm{R}\right)$, for which thousands of traditional ligands, belonging to many different chemical structures, have been synthesized and evaluated. However, this has had only limited success in bringing them to the clinic. In fact, only three natural derived medicines (Marinol $^{\mathrm{TM}}$, Nabilone ${ }^{\mathrm{TM}}$, and Sative ${ }^{\mathrm{TM}}$ ) are available largely due to their unwanted side effects.

One possibility to overcome the limitations of these traditional cannabinoids interacting with the orthosteric sites would be to use allosteric cannabinoid ligands. Despite the considerable research undertaken on traditional cannabinoid agonists and antagonists, there have been comparatively few reports on allosteric cannabinoid ligands. In this review, we will give an overview of the chemical structures that have been tested and proven to be allosteric cannabinoid ligands, but will not deeply deal with the pharmacological as- pects of cannabinoid allosterism, which has been covered elsewhere. ${ }^{6-9}$ According to structural features, $\mathrm{CB}_{1} \mathrm{R}$ allosteric modulators reported to date can be classified as follows: indole derivatives; urea derivatives; and structures acting as endogenous ligands and miscellaneous structures.

\section{Indole Derivatives}

The first evidence for an allosteric binding site on $\mathrm{CB}_{1} \mathrm{R}$ was revealed in 2005 by pharmacological studies realized on three indoles from the company Organon Research, Org27569, Org29647, and Org27759 (Fig. 1). ${ }^{10}$ Among them, Org27569 has been more widely studied and is considered as a prototypical $\mathrm{CB}_{1} \mathrm{R}$ allosteric modulator. Org27569 behaves as a positive allosteric enhancer of agonist binding, whereas in terms of functionality, Org27569 is considered a NAM. Lately, the effect of Org27569 as a NAM has been confirmed in a neuronal model of endocannabinoid synaptic transmission. ${ }^{11}$ However, when tested in vivo, Org27569 lacked efficacy in modulating the action of orthosteric cannabinoids. ${ }^{12}$ Thus, controversial pharmacological data led to a very recent study in which the allosteric effects of Org27569 at $\mathrm{CB}_{1} \mathrm{R}$ have been revealed to be pathway specific and time dependent, suggesting a more complex process than initially proposed. ${ }^{13}$

The Org27569-binding site has been determined by Shore et al. ${ }^{14}$ using a combination of molecular modeling, mutation, and functional assays. This site was identified in the $\mathrm{CB}_{1} \mathrm{R}$ transmembrane helix (TMH)3-6-7 region. Org 27569 acts by modulating receptor activity through conformational changes in the receptor. The authors described how Org27569 sterically blocked
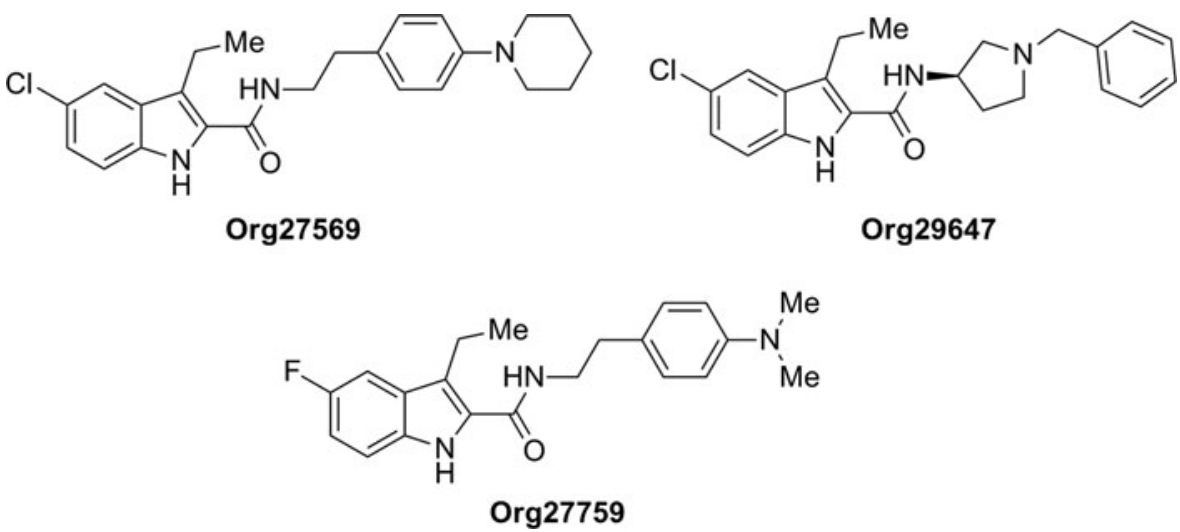

FIG. 1. Structure of indoles Org27569 (pharmacological profile in Table 1), Org29647, and Org27759. 
movements of the extracellular loops and TMH6 that are involved in receptor activation. Recently, site-directed fluorescence labeling studies reported by Fay et al. ${ }^{15}$ showed that effectively TMH6 movements are associated with G-protein activation, whereas its attached helix eight could be involved in the binding of arrestin triggering the biased signaling pathway.

Following discovery of Org27569, structure-activity relationship (SAR) studies were reported by various research groups confirming that indole-2-carboxamide was a good scaffold for developing allosteric modulators for $\mathrm{CB}_{1} \mathrm{R}$. However, it was only in 2012 that Piscitelli et al. $^{16}$ reported that the first indole-2-carboxamides structurally correlated with Org27569. The very close derivative of Org27759, the indole 1 (Fig. 2), was found to possess the highest positive stimulation of the series on the orthosteric agonist $\mathrm{CP}-55,940$ binding at $\mathrm{CB}_{1} \mathrm{R}$.

A large number of Org27569 analogs have been identified in Kendall and Lu's laboratories. ${ }^{17-19}$ Among them, it is worthy to mention compound 2, the 3-pentyl- $1 H$ - indole-2-carboxamide derivative (Fig. 2), as an allosteric enhancer of $\left[{ }^{3} \mathrm{H}\right]-\mathrm{CP}-55,940$ binding with a markedly high binding cooperativity factor and potent antagonism of agonist-induced GTP $\gamma \mathrm{S}$ binding. ${ }^{18}$ Interestingly, the hexyl and the propyl derivatives of $\mathbf{2}$ induced $\beta$-arrestin 1-mediated pathway-biased signaling. ${ }^{19}$

Very recently, a novel series of $1 \mathrm{H}$-indole 2carboxamides has been reported by Nguyen et al. ${ }^{20}$ The most potent compound 3 (Fig. 2) is reported as a NAM of CP-55,940 at $\mathrm{CB}_{1} \mathrm{R}$ according to calcium mobilization assays.

After a first generation of Org27569 derivatives, new series of 2-phenyl- $1 \mathrm{H}$-indoles have been identified as PAMs at $\mathrm{CB}_{1} \mathrm{R}$. Compound PAM1, also named as GAT211, displayed in Figure 2, exemplifies the series of 3-(2-nitro-1-arylethyl)- $1 \mathrm{H}$-indoles claimed by Thakur et al. ${ }^{21}$ as PAMs for $\mathrm{CB}_{1} \mathrm{R}$ in cAMP functional assays. Due to the presence of a chiral center, GAT211 is a racemic mixture of two optical isomers ( $R$ and $S$ ) that were isolated using supercritical fluid chromatography.<smiles>CCc1c(C(=O)NCCc2ccc(N(C)C)cc2)[nH]c2ccc(Cl)cc12</smiles><smiles>CCCCCc1c(C(=O)NCCc2ccc(N(C)C)cc2)[nH]c2ccc(Cl)cc12</smiles>

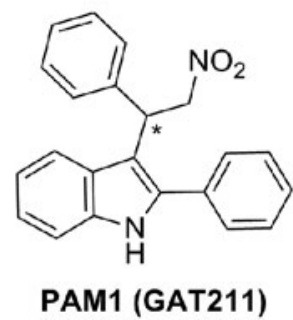<smiles>Cc1ccc2c(C(C[N+](=O)[O-])c3cccs3)c(-c3ccccc3)[nH]c2c1</smiles>

FIG. 2. Indole derivatives as $\mathrm{CB}_{1} \mathrm{R}$ allosteric modulators: 1, 2, 3, ABD1027, PAM1 (GAT211), and ZCZ011 (pharmacological profile in Table 1). *Race MIC mixture. 


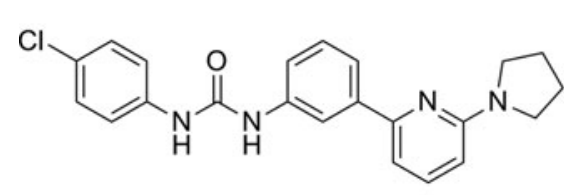

PSNCBAM-1

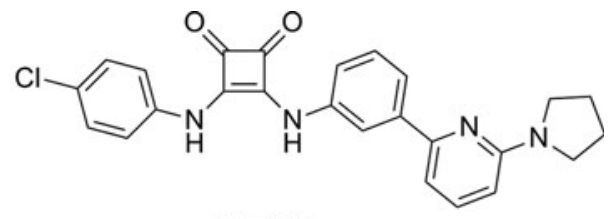

GAT358

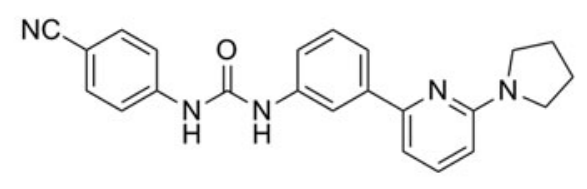

4

FIG. 3. PSNCBAM-1 and its analogs as $C_{1} R$ allosteric modulators: GAT358 and 4 (pharmacological profile in Table 1).

Difference in pharmacology potencies of both enantiomers could be appreciated.

Ignatowska-Jankowska et al. ${ }^{22}$ reported the pharmacological properties of 6-methyl-3-[2-nitro-1-(thiophen-2yl)ethyl]-2-phenyl-1H-indole (ZCZ011; Fig. 2). ZCZ011 increased $\left[{ }^{3} \mathrm{H}\right]-\mathrm{CP}-55,940$ binding and potentiated anandamide (AEA)-stimulated signaling in $\left[{ }^{35} \mathrm{~S}\right]-\mathrm{GTP} \gamma \mathrm{S}$ binding, $\beta$-arrestin recruitment, and extracellular signalregulated kinase (ERK) phosphorylation assays. A very interesting finding is that PAM effects of ZCZ011 could be confirmed by in vivo assays. The indole ZCZ011 exhibited antinociceptive effects in neuropathic and inflammatory pain models with no associated cannabimimetic effects.

Greig et al. ${ }^{23}$ from the University of Aberdeen applied the bioisosteric replacement of carboxamide by sulfonamide leading to numerous $\mathrm{N}$-arylalkyl- $1 \mathrm{H}$ indole-2-sulfonic amides claimed in a patent. Inventors reported that ABD1027 (Fig. 2) did not affect $\left[{ }^{3} \mathrm{H}\right]-\mathrm{CP}$ 55,940 binding, although it inhibited agonist signaling in functional $\beta$-arrestin recruitment assays.

\section{Urea Derivatives}

In 2007, the company Prosidion identified a novel class of $\mathrm{CB}_{1} \mathrm{R}$ allosteric compounds through highthroughput screening of a small library. ${ }^{24}$ The lead optimized urea of this series, PSNCBAM-1 (Fig. 3), increased $\mathrm{CB}_{1} \mathrm{R}$ agonist binding and behaved as an allosteric antagonist in $\left[{ }^{35} \mathrm{~S}\right]-\mathrm{GTP} \gamma \mathrm{S}$ binding and cAMP assays. In this study, acute food intake experiments provided the first in vivo data showing the efficacy of $\mathrm{CB}_{1} \mathrm{R}$ allosteric antagonism similar to the antiobesity effects of the well-known $\mathrm{CB}_{1} \mathrm{R}$ antagonist, SR141716.
In 2015, 8 years after the discovery of PSNCBAM-1, the first SAR studies on PSNCBAM-1 were published by German et al. ${ }^{25}$ The resulting analogs showed similar pharmacological profiles to the parent NAM in binding and calcium mobilization assays. Structural modifications have focused on the pyridine and the 4-chlorophenyl groups. Substituted amine with small size alkyl chains showed to be preferred for pyridine substitution. Substitution in position 4 of the phenyl ring with an electrowithdrawing group was revealed to be important for activity (compound 4; Fig. 3).

In the same year, Thakur et al. ${ }^{26}$ claimed novel $\mathrm{CB}_{1} \mathrm{R}$ allosteric modulators based on PSNCBAM-1 structure. SAR studies involving bioisosterism of urea were extensively examined with the synthesis and evaluation of carbamates, thioureas, 1,3,4-oxadiazol-2-amines, and 3,4-diaminocyclobut-3-ene-1,2-diones, leading to functionally selective NAMs. The 3,4-diaminocyclobut3-ene-1,2-dione derivative, GAT358, was selected for in vivo behavioral tests that suggested minimal $\mathrm{CB}_{1} \mathrm{R}$ inverse agonist-related side effects.

\section{Endogenous $\mathrm{CB}_{1} \mathrm{R}$ Allosteric Modulators}

In addition to synthetic allosteric modulators categorized herein, endogenous molecules of diverse chemical nature have been identified as allosteric modulators of $\mathrm{CB}_{1}$ Rs.

One of these molecules is lipoxin A4 (Fig. 4), an oxygenated derivative of arachidonic acid involved in immune system regulation and known as a potent endogenous anti-inflammatory mediator. However, the specific effects of lipoxin A4 in the CNS were reported to be mediated by unknown mechanisms. In 2012, lipoxin A4 was proposed as an allosteric modulator of 

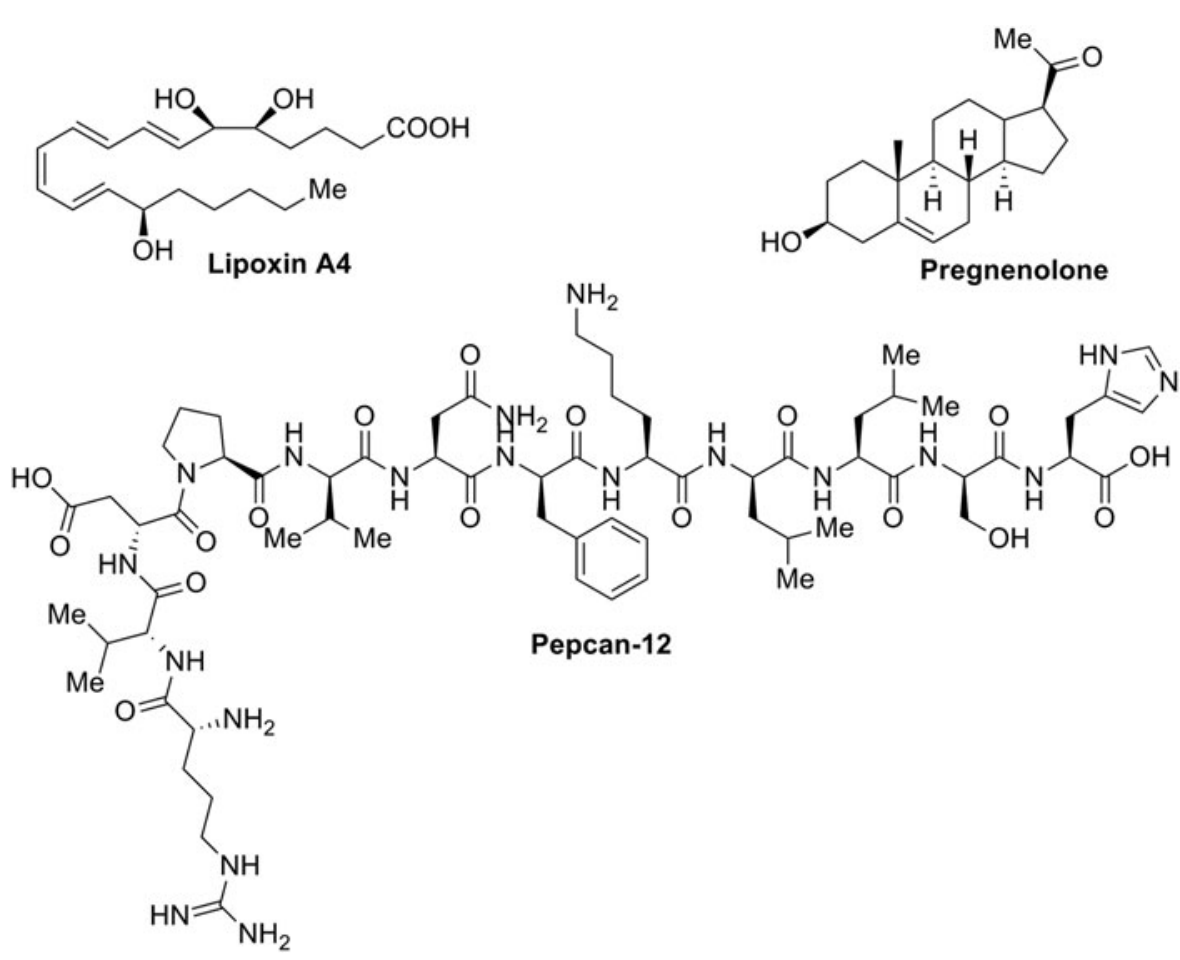

FIG. 4. Endogenous $\mathrm{CB}_{1} \mathrm{R}$ allosteric modulators: lipoxin $\mathrm{A} 4$, pregnenolone, and pepcan-12 (pharmacological profile in Table 1).

$\mathrm{CB}_{1} \mathrm{R}$ by Pamplona et al. ${ }^{27}$ This lipid acted as a $\mathrm{CB}_{1} \mathrm{R}$ $\mathrm{PAM}$, enhancing receptor binding of AEA and $\left[{ }^{3} \mathrm{H}\right]-$ CP-55,940 and not only potentiating selectively AEAversus $2-A G$ in $\mathrm{HEK} 293-\mathrm{CB}_{1} \mathrm{R}$ cells but also in the behavioral tetrad tests. The authors confirmed the therapeutic application for neuroprotection of lipoxin A4 as an allosteric enhancer of $\mathrm{CB}_{1} \mathrm{R}$ activity in an in vivo model of $\beta$-amyloid-induced spatial memory impairment. Recently, Staiker et al. ${ }^{11}$ reported that lipoxin A4 surprisingly exhibited a $\mathrm{CB}_{1} \mathrm{R}$ NAM profile, and no PAM as reported so far, in a neuronal model of 2AG-mediated depolarization-induced suppression of excitation (DSE). Thus, this effect could be attributable to a potential probe dependence of lipoxin A4. Adding to the complexity, recent studies realized by Khajehali et al. ${ }^{13}$ on lipoxin A4 could not corroborate the PAM modulatory effects on either AEA- or CP-55,940-mediated cAMP inhibition in $\mathrm{CHO}-\mathrm{CB}_{1} \mathrm{R}$ cells.

Another putative endogenous allosteric modulator at the $\mathrm{CB}_{1} \mathrm{R}$ is the steroid hormone pregnenolone (Fig. 4), a hydrophobic precursor for all $\mathrm{C}_{18}, \mathrm{C}_{19}$, and $\mathrm{C}_{21}$ steroids directly synthesized from cholesterol. The therapeutic known targets for pregnenolone are
GABA and NMDA receptors. ${ }^{28}$ However, in 2014, Vallée et al. ${ }^{29}$ identified pregnenolone as an allosteric inhibitor at $\mathrm{CB}_{1}$ Rs decreasing $\Delta^{9}$-tetrahydrocannabinol $\left(\Delta^{9}\right.$-THC)-induced ERK1/2 phosphorylation in CHO$\mathrm{CB}_{1} \mathrm{R}$ cells. Furthermore, these NAM effects on $\Delta^{9}$ THC were reproduced in vivo in a behavioral tetrad model, in food intake and memory impairment assays. In contrast, in the neuronal model reported by Staiker et al., ${ }^{11}$ pregnenolone failed to modulate $2-A G$ of synaptic transmission. Likewise, Khajehali et al. ${ }^{13}$ reported lack of modulatory effect of pregnenolone on either $\Delta^{9}$ THC- or WIN55,212-2-induced activation of ERK1/2 phosphorylation. These divergent data suggest probeor pathway-dependent allosteric effects.

Until recently, synthetic or endogenous compounds acting on the endocannabinoid system (ECS) were of lipid nature. In 2012, Bauer et al. ${ }^{30}$ described a 12amino acid sequence, structurally corresponding to an $\mathrm{N}$-terminal extended form of hemopressin, as a potent $\mathrm{CB}_{1} \mathrm{R}$ NAM of orthosteric agonist-induced cAMP accumulation, $\left[{ }^{35} \mathrm{~S}\right]-\mathrm{GTP} \gamma \mathrm{S}$ binding, and receptor internalization. This polypeptide, named pepcan-12, has been recently localized in discrete cells of the 

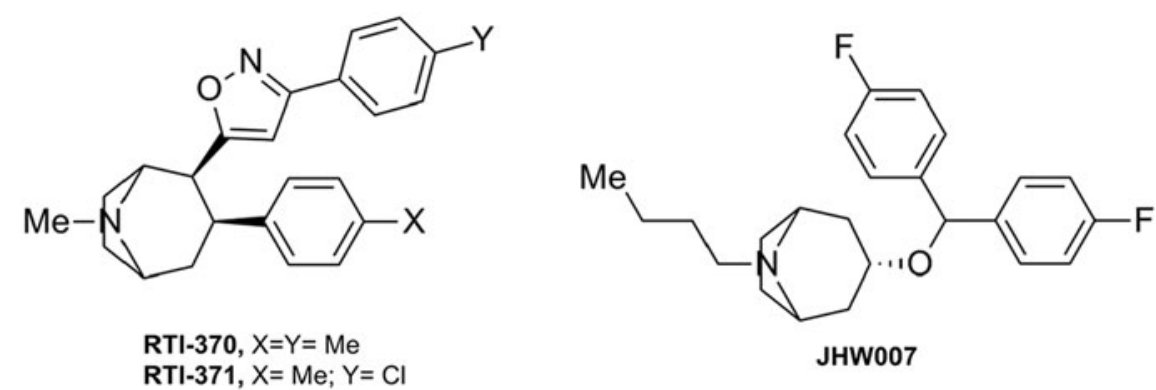

JHW007
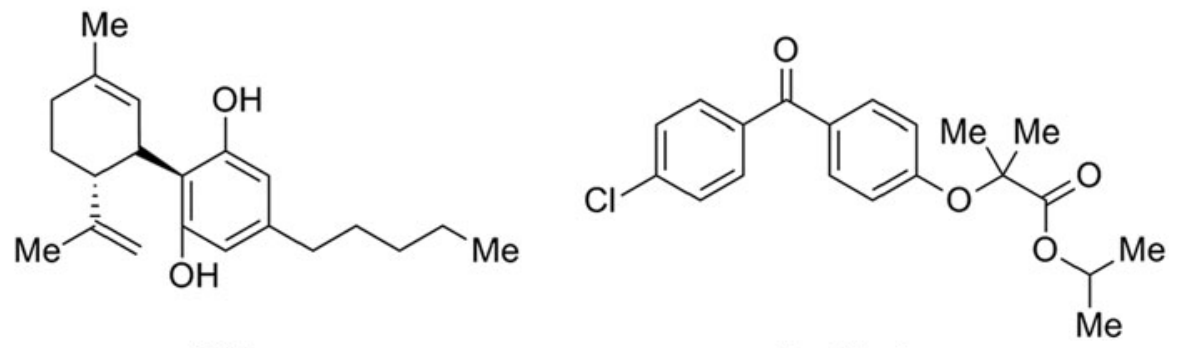

CBD

Fenofibrate

FIG. 5. Miscellaneous $\mathrm{CB}_{1}$ R allosteric modulators: RTI370, RTI371, JHW007, cannabidiol (CBD), and fenofibrate (pharmacological profile in Table 1).

CNS and adrenal gland. ${ }^{31}$ It is worth mentioning that this endocannabinoid peptide was previously reported to interact with $\mathrm{CB}_{1} \mathrm{R}$ as an agonist. ${ }^{32}$ Furthermore, the NAM profile of pepcan-12 has been confirmed in the DSE study of 2-AG synaptic transmission performed by Staiker et al. ${ }^{11}$

\section{Miscellaneous $\mathrm{CB}_{1} \mathrm{R}$ Allosteric Modulators}

The interest gained in this field led to the identification of an assorted range of other small molecules that also display $\mathrm{CB}_{1} \mathrm{R}$ allosteric modulation.

In 2009, researchers from the Research Triangle Park screened several 3-phenyltropane analogs of cocaine for their activity at the $\mathrm{CB}_{1} \mathrm{R}^{33}$ These molecules had been previously characterized as dopamine transporter (DAT) inhibitors. ${ }^{34}$ Among this series, the tropanes, RTI-371 and RTI-370, and the benztropine JHW007 (Fig. 5) stand out as PAMs of CP-55,940induced $\mathrm{CB}_{1} \mathrm{R}$ activity in a cell-based calcium mobilization assay. RTI-371 was found to be of special interest because it is a potent and selective DAT inhibitor that lacks cocaine-like behavioral effects and abuse liability. According to the authors, these atypical cocaine-related effects could be due to positive allosteric modulation of the $\mathrm{CB}_{1} \mathrm{R}^{33}$ This study highlights the potential of the 3 phenyltropane scaffold for the development of novel $\mathrm{CB}_{1} \mathrm{R}$ PAMs.
The nonpsychoactive phytocannabinoid cannabidiol (CBD; Fig. 5) has shown diverse promising therapeutic applications through multiple biological targets. CBD is known to interact with many nonendocannabinoid signaling systems such as the opioid receptors, the transient channel receptor, transient receptor potential channel 1 , or the nuclear receptor, peroxisome proliferatoractivated receptor (PPAR)- $\gamma$, among others. CBD does not bind to the orthosteric $\mathrm{CB}_{1} \mathrm{R}$ binding site; however, it has been shown to display antagonism of $\mathrm{CB}_{1} \mathrm{R}$ agonists in vitro. ${ }^{35-37}$ More recently, Laprairie et al. ${ }^{38}$ provided evidence that $\mathrm{CBD}$ behaved as an NAM of $\Delta^{9}$-THC- and 2-AG-dependent $\mathrm{CB}_{1} \mathrm{R}$ internalization, $\beta$-arrestin recruitment, and phospholipase $\mathrm{C} \beta 3$ - and ERK1/2-phosphorylation. These results may explain some of the in vivo effects of this promising nonpsychoactive compound providing novel insights in the intriguing pharmacology of CBD.

The close relationship between the ECS and the PPARs led to explore the activity of the PPAR- $\alpha$ agonist, fenofibrate $^{39}$ (Fig. 5), in the ECS. This fibrate is an amphipathic molecule that acts as a prodrug formed by fenofibric acid linked to an isopropyl ester. Priestley et al. ${ }^{40}$ reported the pharmacological profile of fenofibrate at CBRs. $\left[{ }^{35} \mathrm{~S}\right]-$ GTP $\gamma S$ binding experiments revealed partial agonism of fenofibrate at $\mathrm{CB}_{1} \mathrm{R}$ and full agonism at $\mathrm{CB}_{2} \mathrm{R}$. Moreover, at higher concentrations, this PPAR- $\alpha$ ligand was 
also able to significantly decrease $\left[{ }^{35} \mathrm{~S}\right]-\mathrm{GTP} \gamma \mathrm{S}$ binding of $\mathrm{CP}-55,940$ acting as an NAM of $\mathrm{CB}_{1} \mathrm{R}$. Thus, the authors suggested two possible interpretations. Fenofibrate could be considered a bitopic ligand at $\mathrm{CB}_{1} \mathrm{R}$ since it binds both orthosteric and allosteric sites or fenofibrate could be an allosteric $\mathrm{CB}_{1} \mathrm{R}$ modulator that could be able to produce by itself a functional response by interacting with a nonorthosteric site at $\mathrm{CB}_{1} \mathrm{R}$.

\section{Conclusions and Perspectives}

The psychoactive side effects generated by activation of $\mathrm{CB}_{1} \mathrm{R}$ in the brain have limited the use of orthosteric
$\mathrm{CB}_{1} \mathrm{R}$ ligands as drugs. However, this receptor plays an important role in diverse processes such as pain, cognition, and metabolism. Alternative targets within the ECS have been proposed, including $\mathrm{CB}_{2} \mathrm{R}$, the fatty acid amide hydrolase, or the monoacylglycerol lipase. Allosteric modulation at $\mathrm{CB}_{1} \mathrm{R}$ offers new opportunities for therapeutic applications. Even though the first $\mathrm{CB}_{1} \mathrm{R}$ allosteric ligand, Org27569, was identified in 2005 , significant interest by the research community only started few years ago. Then, there have been rapidly increasing research efforts directed into $\mathrm{CB}_{1} \mathrm{R}$ allosterism during these last 3 years. This review reflects the

Table 1. Summary of $\mathrm{CB}_{1} \mathrm{R}$ Allosteric Modulators and Their Cannabinoid Pharmacological Profile

\begin{tabular}{|c|c|c|c|c|}
\hline \multirow[b]{2}{*}{ Compound } & \multirow{2}{*}{$\begin{array}{l}\qquad \mathrm{CB}_{1} \mathrm{R} / \mathrm{CB}_{2} \mathrm{R} \\
\text { orthosteric modulation }\end{array}$} & \multirow{2}{*}{$\begin{array}{l}\mathrm{CB}_{1} \mathrm{R} \text { allosteric } \\
\text { modulation }\end{array}$} & \multicolumn{2}{|l|}{$\mathrm{CB}_{1} \mathrm{R}$ allosterism } \\
\hline & & & Functional outcome (orthosteric ligand) & References \\
\hline \multirow[t]{4}{*}{ Org27569 } & $\mathrm{CB}_{1} \mathrm{R}$ inverse agonist ${ }^{6}$ & NAM & $\begin{array}{l}\left.{ }^{35} \mathrm{~S}\right]-\mathrm{GTP} \gamma \mathrm{S} \text { binding assay }{ }^{\mathrm{a}}(\mathrm{CP}-55,940 ; \mathrm{AEA}), \mathrm{cAMP} \\
\text { assay, } \beta \text {-arrestin recruitment }{ }^{\mathrm{a}}(\mathrm{CP}-55,940 ; \\
\text { WIN55,212, AEA) }\end{array}$ & Price et al. $2005^{10}$ \\
\hline & & PAM & ERK1/2 phosphorylation ${ }^{a}(C P-55,940)$ & Baillie et al. $2013^{6}$ \\
\hline & & NAM & ERK1/2 phosphorylation ${ }^{a}(2-A G)$ & Khajehali et al. $2015^{13}$ \\
\hline & & NAM & $\operatorname{DSE}^{\mathrm{C}}(2-\mathrm{AG})$ & Straiker et al. $2015^{11}$ \\
\hline 2 & - & NAM & {$\left[{ }^{35} \mathrm{~S}\right]-\mathrm{GTP} \gamma \mathrm{S}$ binding assay ${ }^{\mathrm{b}}(\mathrm{CP}-55,940)$} & Mahmoud et al. $2013^{18}$ \\
\hline 3 & - & NAM & $\mathrm{Ca}^{2+}$ mobilization assay ${ }^{\mathrm{a}}(\mathrm{CP}-55,940)$ & Nguyen et al. $2015^{20}$ \\
\hline PAM1 (GAT211) & - & PAM & cAMP assay $(\mathrm{CP}-55,940)$ & Thakur et al. $2013^{21}$ \\
\hline \multirow[t]{4}{*}{ ZCZ011 } & $\mathrm{CB}_{1} \mathrm{R}$ agonist ${ }^{22}$ & PAM & {$\left[{ }^{35}\right.$ S]-GTP $\gamma S$ binding assay ${ }^{d}(C P-55,940 ; A E A)$} & $\begin{array}{l}\text { Ignatowska-Jankowska } \\
\text { et al. } 2015^{22}\end{array}$ \\
\hline & & NE & 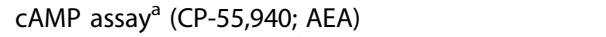 & \\
\hline & & PAM & ERK1/2 phosphorylation ${ }^{\mathrm{a}}$ (CP-55,940; AEA) & \\
\hline & & PAM & $\beta$-arrestin recruitment ${ }^{\mathrm{b}}(\mathrm{AEA})$ & \\
\hline ABD1027 & - & NAM & $\beta$-arrestin recruitment ${ }^{\mathrm{b}}(\mathrm{CP}-55,940)$ & Greig et al. $2012^{23}$ \\
\hline \multirow[t]{4}{*}{ PSNCBAM-1 } & $\mathrm{CB}_{1} \mathrm{R}$ partial inverse agonist ${ }^{24}$ & NAM & $\begin{array}{l}{ }^{35} \text { S]-GTP } \gamma \text { S binding assay }{ }^{\mathrm{b}}(\mathrm{CP}-55,940 ; \mathrm{AEA}), \mathrm{cAMP} \\
\text { assay }^{\mathrm{b}} \text { (CP-55,940; AEA) }\end{array}$ & Horswill et al. $2007^{24}$ \\
\hline & & NAM & {$\left[{ }^{35} \mathrm{~S}\right]-\mathrm{GTP} \gamma \mathrm{S}$ binding assay ${ }^{\mathrm{e}}(\mathrm{CP}-55,940 ;$ WIN55,212) } & Wang et al. $2011^{41}$ \\
\hline & & NAM & $\beta$-arrestin recruitment ${ }^{\mathrm{a}}(\mathrm{CP}-55,940 ; \mathrm{WIN} 55,212)$ & Baillie et al. $2013^{6}$ \\
\hline & & NAM & $\operatorname{DSE}^{\mathrm{C}}(2-\mathrm{AG})$ & Straiker et al. $2015^{11}$ \\
\hline 4 & - & NAM & $\mathrm{Ca}^{2+}$ mobilization assay ${ }^{\mathrm{f}}(\mathrm{CP}-55,940)$ & German et al. $2014^{25}$ \\
\hline GAT358 & - & NAM & $\begin{array}{l}\text { CAMP assay (CP-55,940), } \beta \text {-arrestin recruitment }{ }^{\mathrm{b}} \\
(\mathrm{CP}-55,940)\end{array}$ & Thakur et al. $2015^{26}$ \\
\hline \multirow[t]{3}{*}{ Lipoxin A4 } & $\mathrm{NE}^{27}$ & PAM & cAMP assay ${ }^{b}(A E A)$ & Pamplona et al. $2012^{27}$ \\
\hline & & NAM & $\mathrm{DSE}^{\mathrm{c}}(2-\mathrm{AG})$ & Straiker et al. $2015^{11}$ \\
\hline & & NE & cAMP assay $^{\text {a }}($ AEA; CP-55,940) & Khajehali et al. $2015^{13}$ \\
\hline \multirow[t]{3}{*}{ Pregnenolone } & - & NAM & ERK1/2 phosphorylation ${ }^{\mathrm{a}}\left(\Delta^{9}-\mathrm{THC}\right)$ & Vallée et al. $2014^{29}$ \\
\hline & & NE & $\operatorname{DSE}^{\mathrm{C}}(2-\mathrm{AG})$ & Straiker et al. $2015^{11}$ \\
\hline & & NE & ERK1/2 phosphorylation ${ }^{\mathrm{a}}\left(\Delta^{9}-\mathrm{THC}, \mathrm{WIN} 55,212\right)$ & Khajehali et al. $2015^{13}$ \\
\hline \multirow[t]{2}{*}{ Pepcan 12} & $\mathrm{CB}_{1} \mathrm{R}$ agonist ${ }^{32}$ & NAM & $\begin{array}{l}\text { cAMP assay, }\left[{ }^{35} \mathrm{~S}\right]-\mathrm{GTP} \gamma \mathrm{S} \text { binding, } \mathrm{CB}_{1} \mathrm{R} \\
\text { internalization }{ }^{\mathrm{a}}(2-\mathrm{AG}, \text { WIN55,212, HU210) }\end{array}$ & Bauer et al. $2012^{30}$ \\
\hline & & NAM & $\operatorname{DSE}^{\mathrm{C}}(2-\mathrm{AG})$ & Straiker et al. $2015^{11}$ \\
\hline RTI-371 & $\mathrm{NE}^{33}$ & PAM & $\mathrm{Ca}^{2}+$ mobilization assay $^{\mathrm{a}}(\mathrm{CP}-55,940)$ & Navarro et al. $2009^{33}$ \\
\hline CBD & Weak $\mathrm{CB}_{1} \mathrm{R} / \mathrm{CB}_{2} \mathrm{R}$ antagonist ${ }^{36,37}$ & NAM & $\begin{array}{l}\text { PLC } \beta 3 \text { - and ERK } 1 / 2 \text { phosphorylation, } \beta \text {-arrestin } \\
\text { recruitment }^{\mathrm{b}, \mathrm{g}}\left(\Delta^{9}-\mathrm{THC}, 2-\mathrm{AG}\right)\end{array}$ & Laprairie et al. $2015^{38}$ \\
\hline Fenofibrate & $C B_{1} R$ partial agonist/ $C B_{2} R$ agonist ${ }^{40}$ & NAM & $\left.{ }^{35} \mathrm{~S}\right]-\mathrm{GTP} \gamma \mathrm{S}$ binding ${ }^{\mathrm{a}}(\mathrm{CP}-55,940)$ & Priestley et al. $2015^{40}$ \\
\hline
\end{tabular}

${ }^{\mathrm{a}} \mathrm{CHO}-\mathrm{CB}_{1} \mathrm{R}$ cells.

${ }^{\mathrm{b}} \mathrm{HEK} 293-\mathrm{CB}_{1} \mathrm{R}$.

'Hippocampal neurons.

dMouse brain membranes.

${ }^{\text {e}}$ Cerebellar membranes.

${ }^{\mathrm{R}} \mathrm{D}-\mathrm{HGA} 16-\mathrm{CB}_{1} \mathrm{R}$ cells.

${ }^{9} \mathrm{STH} d h^{\mathrm{Q} 7 / \mathrm{Q} 7}-\mathrm{CB}_{1} \mathrm{R}$.

$\Delta^{9}$-THC, $\Delta^{9}$-tetrahydrocannabinol; AEA, anandamide; CBD, cannabidiol; DSE, depolarization-induced suppression of excitation; ERK, extracellular signal-regulated kinase; NAM, negative allosteric modulator; NE, no effect; PAM, positive allosteric modulator; PLC, phospholipase C. 
structural diversity and nature of the $\mathrm{CB}_{1} \mathrm{R}$ allosteric modulators identified so far. In particular, there has been an increasing identification of endogenous allosteric modulators that offer new insights in the intriguing pharmacology of $\mathrm{CB}_{1} \mathrm{R}$. In Table 1 , a summary of the pharmacological profile of diverse $\mathrm{CB}_{1} \mathrm{R}$ allosteric modulators is displayed. It is worth mentioning that in several of the studies discussed above, there is no correlation between the different cell-based pharmacological data. Moreover, the in vitro data do not always translate to in vivo effects. These divergent functional data may account for signaling-specific allosteric modulation as well as orthosteric probe dependence. Subsequently, there is a clear need for developing more allosteric pharmacological tools for understanding this complex pharmacology.

The characterization of small molecules as allosteric modulators of $\mathrm{CB}_{1}$ Rs provides the basis for future design and synthesis of optimized allosteric modulators. Efforts need to be made to expand these scaffolds and obtain structural information about the ligandallosteric site interactions. Further understanding of the chemical features required for allosteric modulation as well as their orthosteric probe dependence may broaden novel approaches for fine-tuning the signaling pathways of the $\mathrm{CB}_{1} \mathrm{R}$.

\section{Acknowledgments}

The authors gratefully acknowledge research support from Spanish Grants SAF2012-400075-C02-02 of the Spanish Ministry and S2010/BMD-2308 of CAM. P.M. is recipient of a fellowship JAE-Pre-2010-01119 from "Junta para la Ampliación de Estudios" cofinanced by FSE.

\section{Author Disclosure Statement}

No competing financial interests exist.

\section{References}

1. Gentry PR, Sexton PM, Christopoulos A. Novel allosteric modulators of G protein-coupled receptors. J Biol Chem. 2015;290:19478-19488.

2. Westhuizen ET, Valant C, Sexton PM, et al. Endogenous allosteric modulators of $\mathrm{G}$ protein-coupled receptors. J Pharmacol Exp Ther. 2015:353:246-260.

3. Conn PJ, Lindsley CW, Meiler J, et al. Opportunities and challenges in the discovery of allosteric modulators of GPCRs for treating CNS disorders. Nat Rev Drug Discov. 2014;13:692-708.

4. Nickols HH, Conn PJ. Development of allosteric modulators of GPCRs for treatment of CNS disorders. Neurobiol Dis. 2014;61:55-71.

5. Burford NT, Traynor JR, Alt A. Positive allosteric modulators of the $\mu$ opioid receptor: a novel approach for future pain medications. $\mathrm{Br}$ J Pharmacol. 2015;172:277-286.

6. Baillie GL, Horswill JG, Anavi-Goffer S, et al. CB(1) receptor allosteric modulators display both agonist and signaling pathway specificity. Mol Pharmacol. 2013;83:322-338.
7. Cawston EE, Redmond WJ, Breen CM, et al. Real-time characterization of cannabinoid receptor 1 (CB1) allosteric modulators reveals novel mechanism of action. Br J Pharmacol. 2013;170:893-907.

8. Ross RA. Tuning the endocannabinoid system: allosteric modulators of the CB1 receptor. Br J Pharmacol. 2007;152:565-566.

9. Picone RP, Kendall D. Minireview: from the bench, toward the clinic: therapeutic opportunities for cannabinoid receptor modulation. Mol Endocrinol. 2015;29:801-813.

10. Price MR, Baillie GL, Thomas A, et al. Allosteric modulation of the cannabinoid CB1 receptor. Mol Pharmacol. 2005;68:1484-1495.

11. Straiker A, Mitjavila J, Yin D, et al. Aiming for allosterism: evaluation of allosteric modulators of CB1 in a neuronal model. Pharmacol Res. 2015;99:370-376.

12. Gamage T, Ignatowska-Jankowska B, Wiley JL, et al. In-vivo pharmacological evaluation of the CB1-receptor allosteric modulator Org-27569. Behav Pharmacol. 2014;25:182-185.

13. Khajehali E, Malone DT, Glass $M$, et al. Biased agonism and biased allosteric modulation at the CB 1 cannabinoid receptors. Mol Pharmacol. 2015;88:368-379.

14. Shore DM, Baillie GL, Hurst DH, et al. Allosteric modulation of a cannabinoid $G$ protein-coupled receptor binding site elucidation and relationship to $G$ protein signaling. J Biol Chem. 2014;289:5828-5845.

15. Fay JF, Farrens DL. Structural dynamics and energetics underlying allosteric inactivation of the cannabinoid receptor CB 1. Proc Natl Acad Sci. 2015;112:8469-8474

16. Piscitelli F, Ligresti $A$, La Regina $G$, et al. Indole-2-carboxamides as allosteric modulators of the cannabinoid $\mathrm{CB}(1)$ receptor. J Med Chem. 2012;55:5627-5631.

17. Ahn $\mathrm{KH}$, Mahmoud MM, Samala $\mathrm{S}$, et al. Profiling two indole-2 carboxamides for allosteric modulation of the CB1 receptor. J Neurochem. 2013;29:997-1003.

18. Mahmoud MM, Ali HI, Ahn KH, et al. Structure-activity relationship study of indole-2-carboxamides identifies a potent allosteric modulator for the cannabinoid receptor 1 (CB1). J Med Chem. 2013;56:7965-7975.

19. Khurana L, Ali HI, Olszewska T, et al. Optimization of chemical functionalities of indole-2-carboxamides to improve allosteric parameters for the cannabinoid receptor 1 (CB1). J Med Chem. 2014;57:3040-3052.

20. Nguyen T, German N, Decker AM, et al. Structure-activity relationships of substituted $1 \mathrm{H}$-indole-2-carboxamides as CB1 receptor allosteric modulators. Bioorg Med Chem. 2015;23:2195-2203.

21. Thakur GA, Kulkarni PM. Allosteric modulators of CB1 cannabinoid receptors. Patent. 2013;WO2013103967.

22. Ignatowska-Jankowska BM, Baillie GL, Kinsey S, et al. A cannabinoid CB1 receptor-positive allosteric modulator reduces neuropathic pain in the mouse with no psychoactive effects. Neuropsychopharmacology. 2015;40:2948-2959.

23. Greig IR, Ross RA, Pertwee RG, et al. N-(Arylalkyl)-1H-indole-2-sulfonic acid amide compounds and their therapeutic use as cannabinoid allosteric modulators. Patent. 2012;WO2012117216.

24. Horswill JG, Bali U, Shaaban S, et al. PSNCBAM-1, a novel allosteric antagonist at cannabinoid $C B 1$ receptors with hypophagic effects in rats. $\mathrm{Br}$ J Pharmacol. 2007;152:805-814.

25. German N, Decker AM, Gilmour BP, et al. Diarylureas as allosteric modulators of the cannabinoid CB1 receptor: structure-activity relationship studies on 1-(4- Chlorophenyl)-3-\{3-[6-(pyrrolidin-1-yl)pyridin-2-yl] phenyl\}urea (PSNCBAM-1). J Med Chem. 2014;57:7758-7769.

26. Thakur GA, Tichkule RB, Kulkarni PM, et al. Allosteric modulators of the cannabinoid 1 receptor. Patent. 2015;WO2015027160.

27. Pamplona FA, Ferreira J, Menezes de Lima O, et al. Anti-inflammatory lipoxin A4 is an endogenous allosteric enhancer of CB1 cannabinoid receptor. Proc Natl Acad Sci. 2012;109:21134-21139.

28. Baulieu EE, Robel P, Schumacher M. Neurosteroids: beginning of the story. Int Rev Neurobiol. 2001;46:1-32.

29. Vallée M, Vitiello S, Bellocchio L, et al. Pregnenolone can protect the brain from cannabis intoxication. Science. 2014;343:94-98.

30. Bauer M, Chicca A, Tamborrini M, et al. Identification and quantification of a new family of peptide endocannabinoids (Pepcans) showing negative allosteric modulation at CB1 receptors. J Biol Chem. 2012;287:3694436967.

31. Hofer SC, Ralvenius WT, Gachet MS, et al. Localization and production of peptide endocannabinoids in the rodent CNS and adrenal medulla. Neuropharmacology. 2015;98:78-89. 
32. Gomes I, Grushko JS, Golebiewska U, et al. Novel endogenous peptide agonists of cannabinoid receptors. FASEB J. 2009;23:3020-3029.

33. Navarro HA, Howard JL, Pollard GT, et al. Positive allosteric modulation of the human cannabinoid (CB1) receptor by RTI-371, a selective inhibitor of the dopamine transporter. Br J Pharmacol. 2009;156:1178-1184.

34. Carroll Fl, Pawlush N, Kuhar MJ, et al. Synthesis, monoamine transporter binding properties, and behavioral pharmacology of a series of 3beta(substituted phenyl)-2beta-(3'-substituted isoxazol-5-yl)tropanes. J Med Chem. 2004;47:296-302.

35. Hayakawa K, Mishima K, Hazekawa M, et al. Cannabidiol potentiates pharmacological effects of Delta(9)-tetrahydrocannabinol via $\mathrm{CB}(1)$ receptor-dependent mechanism. Brain Res. 2008;1188:157-164.

36. Pertwee RG, Ross RA, Craib SJ, et al. (-)-Cannabidiol antagonizes cannabinoid receptor agonists and noradrenaline in the mouse vas deferens. Eur J Pharmacol. 2002;456:99-106.

37. Thomas A, Baillie GL, Phillips AM, et al. Cannabidiol displays unexpectedly high potency as an antagonist of $C B 1$ and $C B 2$ receptor agonists in vitro. Br J Pharmacol. 2007;150:613-623.

38. Laprairie RB, Bagher AM, Kelly MEM, et al. Cannabidiol is a negative allosteric modulator of the type 1 cannabinoid receptor. $\mathrm{Br} J$ Pharmacol. 2015 (in press).

39. Liu Z-M, Hu M, Chan P, et al. Early investigational drugs targeting PPAR- $\alpha$ for the treatment of metabolic disease. Expert Opin Investig Drugs. 2015;24:611-621.

40. Priestley RS, Nickolls SA, Alexander SPH, et al. A potential role for cannabinoid receptors in the therapeutic action of fenofibrate. FASEB J. 2015;29:1446-1455.

41. Wang X, Horswill JG, Whalley BJ, et al. Effects of the allosteric antagonist 1-(4-Chlorophenyl)-3-[3-(6-pyrrolidin-1-ylpyridin-2-yl) phenyl] urea (PSNCBAM-1) on CB1 receptor modulation in the cerebellum. Mol Pharmacol. 2011;79:758-767.
Cite this article as: Morales $\mathrm{P}$, Goya $\mathrm{P}$, Jagerovic N, Hernandez Folgado $L$ (2016) Allosteric modulators of the $C_{1}$ cannabinoid receptor: a structural update review, Cannabis and Cannabinoid Research 1.1, 22-30, DOI: 10.1089/can.2015.0005.

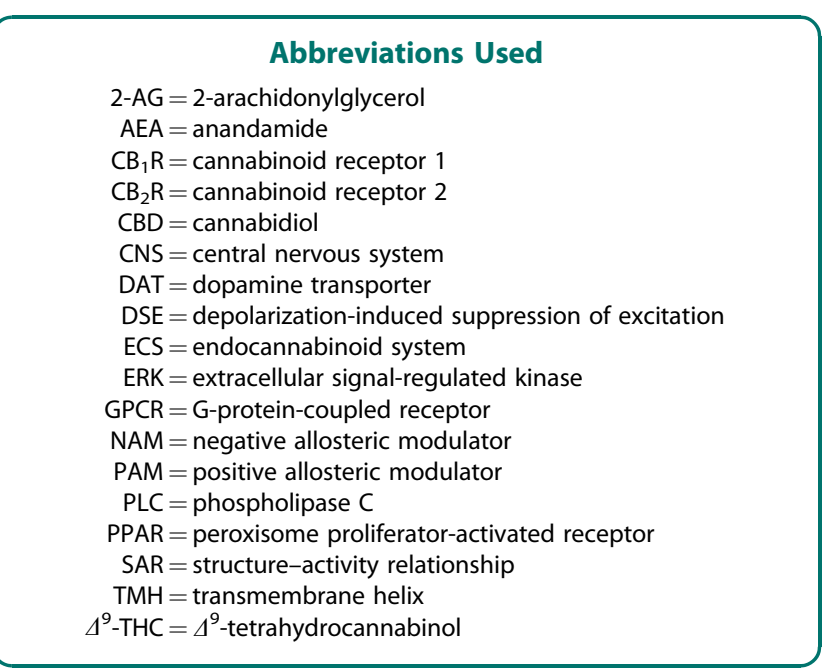

\section{Publish in Cannabis and Cannabinoid Research}

Cannabis and

Cannabinoid

Research
- Immediate, unrestricted online access

- Rigorous peer review

- Compliance with open access mandates

- Authors retain copyright

- Highly indexed

- Targeted email marketing

liebertpub.com/can 